\title{
Development of Latex Enhanced Qualitative Immuno Assay for High Sensitivity CRP Detection
}

\author{
Praveena $^{1 *}$, C.V. Raghuveer ${ }^{2}$ and D.M. Vasudevan ${ }^{3}$ \\ ${ }^{1}$ Yenepoya university, Deralakatte, Mangalore, Karnataka, India- 575018 \\ ${ }^{2}$ Sri Devaraj Urs Academy of Higher Education \& Research, Kolar, \\ Karnataka - 563 101, India \\ ${ }^{3}$ Agape, Cochin, Kerala - 683562, India \\ *Corresponding author
}

\section{A B S T R A C T}

High-sensitivity C-reactive protein (hsCRP) is an important marker of inflammation to predict the risk of CVDs. Existing reagent system for the detection of hs CRP has its limitation such as higher cost and requirement of sophisticated instruments, which minimize the utility of this effective marker utility in Indian population. The study was

\section{Keywords}

Hs CRP,

agglutination, Stabilising agent,

Latex beads, Colloidal stability

Article Info

Accepted:

20 May 2019

Available Online:

10 June 2019 aimed to formulate and validate an improved reagent system for the detection of hs CRP. The study was targeted to formulate a latex-enhanced reagent format by selecting inert microscopic latex particles. Antibody titration for optimal coating was confirmed in different standard conditions. Reaction buffer characterization for colloidal stability was confirmed and sensitivity setting of the reagent was carried out. Performance validation of the assay was carried by confirming sensitivity, specificity, and precision. Studies of Interference substance testing was carried out for hemoglobin and Bilirubin. The prepared reagent system were tested and compared with existing standard hs CRP reagent systems. An effective reagent system was prepared by selecting Thermo fisher latex of size $0.46 \mu \mathrm{m}$ with functional modification as carboxyl modified latex. Protein optimization trial yield as $500 \mu \mathrm{g}-750 \mu \mathrm{g}$ of Anti CRP required for $1 \mathrm{mg}$ weight latex. BSA $1 \% \mathrm{w} / \mathrm{v}$ showed good colloidal stability at room temperature and at $37^{\circ} \mathrm{C}$. Performance validation of the assay was carried out and confirmed the sensitivity specificity, precision and interference testing on hemoglobin and Bilirubin. Comparison of the sample with existing reagent systems shows the effectiveness of the reagent system the prepared reagent formulation was rapid, cost effective, and reproducible and was comparable with the reference method used in clinical practice. The advantage of this proposed methodology is that it does not require any high end automated systems for the estimation.

\section{Introduction}

Cardiovascular diseases have now become the leading cause of mortality in India. A quarter of all mortality is attributable to CVD.[1]
Some aspects of the CVD epidemic in India are particular causes of concern, including its accelerated buildup, the early age of disease onset in the population, and the high case fatality rate. Health care expenditures are 
overwhelming national and corporate budgets, predominantly because of the escalating cost of advanced disease. [2] Therefore there is an urgent need for early detection and treatment of asymptomatic cardiovascular disease. The traditional approach to cardiovascular disease prevention involves identifying risk factors that are statistically but not necessarily biologically related to disease, but numerous biological markers that are molecular indicators of several pathophysiological stages of nature evolution CVD could become a powerful and reliable tool for more exact risk prognostication and accurate predictors of treatment response in CVD [3].

Hs-CRP is considered to be a consistent marker for evaluating the extent of future CVD in all populations. But the utility of $\mathrm{Hs}$ CRP estimation for the CVD risk assessment in the Indian population is very low. [4] This can be due to the lack of awareness among the population or the high cost of the test. In India only very few laboratories in the rural sector are carrying out Hs CRP assessment, which is again a reason that Hs CRP estimation is not popular among the diabetic and non-diabetic population. [5] The currently available reagent systems used for the detection of $\mathrm{Hs}$ CRP are imported and requires highly sophisticated instruments for the detection. No market available kits are of Indian origin and the present study focus on the indigenous development of a latex based reagent assay which requires no instrument and minimum technical expertise to perform the test [6]. The present study was targeted to develop a reagent system that is rapid, cost effective and can be performed within a primary health care center. The study was planned to formulate a latex-enhanced reagent format, inert microscopic latex particles enlarge the immune complexes, amplifying the reaction and significantly increasing the sensitivity of the reaction. Initially the study was targeted to have an optimization of a qualitative and semi quantitative high sensitive latex reagent for the detection of Hs CRP by Protein purification and characterization, latex bead selection on size and functional group, covalent binding of Anti Hs CRP to the latex protocol development, antibody titration for optimal coating, reaction buffer characterization for colloidal stability, and sensitivity setting of the reagent.

\section{Materials and Methods}

The antibody against human $\mathrm{C}$ reactive protein was obtained commercially and purified by affinity chromatographic technique, stored at -20 degree in different aliquots. Different size latex beads from different sources like Thermoscientific, Sigma, and Magsphere are procured. Selection of the size and functional group of Latex beads has been done by trial and error method. The efficiency of the assay was checked by the visible agglutination reaction pattern with the highest and lowest CRP calibrator.

\section{Covalent binding of Anti Hs CRP to the latex protocol development}

The latex beads are washed and diluted using a washing buffer to the 0.1 to $1.0 \% \mathrm{v} / \mathrm{w}$ concentration. These diluted latex beads were subjected to an activation process and to this different concentration of the anti CRP protein were added and incubated. All latex particles obtained commercially were $10 \%$ aqueous solutions with and without surfactants. The particles were washed with MES buffer to remove the surfactants and made it to $1 \%$ solution. The passive adsorption property is checked with 6 hours incubation with $50 \mu \mathrm{l}$ anti CRP antibody solution of $5 \mathrm{mg} / \mathrm{ml}$. The incubation is done with constant agitation at $37^{\circ} \mathrm{C}$ incubator. The latex was washed with MES buffer after incubation for removal of any unbound 
antibodies. The coated latex was checked for visual agglutination with the CRP positive control serum on the black slides. Trials on covalent coupling reactions with the different sources of latex size beads and antibodies of different sources is coded as latex 1-9 and Anti CRP antibody as Antibody 1-4. Initial trials with nine different types of latex were employed for passive agglutination with monoclonal and polyclonal anti CRP antibodies. Latex size ranges from $0.33 \mu \mathrm{m}$ to $0.82 \mu \mathrm{m}$ was used to study the clarity of agglutination reaction. When compared, medium sized particles as $0.46 \mu \mathrm{m}, 0.49 \mu \mathrm{m}$ and $0.5 \mu \mathrm{m}$ showed better reaction. More trials was done with clinical samples of $\mathrm{Hs}$ CRP concentration $1 \mathrm{mg} / \mathrm{L}, 4 \mathrm{mg} / \mathrm{L}$ and 10 $\mathrm{mg} / \mathrm{L}$. The carboxyl modified latex of size 0.46um was selected for further studies and polyclonal anti CRP antibody is tried for covalent coupling.

\section{Antibody titration for optimal coating}

The resulting assay is again tested for the titration of protein, which was coupled to the latex beads using BCA assay. This methodology is to optimize the minimum amount of anti CRP antibody required to saturate the latex beads. The amount of anti CRP antibody required to coat for a monolayer of latex is calculated. Trials are done to estimate the amount of protein to be used to achieve the maximum saturation with minimum concentration of anti CRP antibody.

\section{Micro Protein estimation with BCA assay}

To estimate the correct amount of Anti CRP antibody coated on the latex was done by BCA assay kit for micro protein estimation. The supernatant obtained during the washing procedure after the covalent coupling is done using the BCA assay. The two concentration of anti CRP antibody used are $100 \mu \mathrm{l}$ and $150 \mu \mathrm{l}(5 \mathrm{mg} / \mathrm{ml})$ to $1 \mathrm{ml}$ of $1 \%$ latex suspension.

\section{Performance validation of the assay}

\section{Sensitivity and specificity}

Analytical sensitivity is described as the performance of the lower side of the measurement range. The sensitivity setting of the latex reagent was carried out by trial and error method on ionic strength and $\mathrm{pH}$ of the final reaction buffer. Trials with different $\mathrm{pH}$ of same Tris buffer is done to check the clarity and agglutination pattern with saline control, positive control and two different calibrator concentration $10 \mathrm{mg} / \mathrm{L}$ and $1 \mathrm{mg} / \mathrm{L}$. Different concentrations of $\mathrm{NaCl}$ is used to adjust the sensitivity of the assay.

\section{Precision}

Testing was done with 20 replicates of negative and positive samples at concentration within $20 \%$ of the cut off. Two samples were made by values hiked using the CRP calibrator, the values taken was 0.8 $\mathrm{mg} / \mathrm{L}$ as negative and $1.2 \mathrm{mg} / \mathrm{L}$ as positive value. The agglutination was replicated 20 times at the same laboratory condition. False positive and false negative incidence was studied.

\section{Intra run study -Precision study}

A sample of known value of $4 \mathrm{mg} / \mathrm{L}$ was used for the intra run study. Agglutination was done at the same laboratory conditions. Ten repeats are done on direct sample and $1 / 2$ dilution and $1 / 4$ dilution with saline.

\section{Inter run study - Precision study}

A sample of known value of $4 \mathrm{mg} / \mathrm{L}$ was used for the inter run study. Agglutination was done at different time as $10 \mathrm{am}, 1.30 \mathrm{pm}$ and $4 \mathrm{pm}$ in the same laboratory conditions. Ten repeats were done on direct sample and $1 / 2$ dilution and $1 / 4$ dilution with saline. 


\section{Studies of Interference substance testing}

Interference study is done to characterize the effects of potential interferent on assay performance.

\section{Interference from hemoglobin}

The interference study was performed by testing Hs CRP antibody latex reagent on plasma pools spiked at different concentration of hemolysate in the present study the hemolysate with hemoglobin level of $120 \mathrm{~g} / \mathrm{L}$ used as stock solution.

The stock solution of hemolysate was diluted 1:2, 1:4, 1:8, 1:20 and 1:40 with normal saline and obtains the stock solutions with hemoglobin levels $60,30,15,6,3 \mathrm{~g} / \mathrm{L}$ respectively. From the above stock solution $100 \mu \mathrm{L}$ is transferred to $900 \mu \mathrm{L}$ serum containing different concentration of CRP. The final hemolysate concentration in serum is $6,3,1.5,0.6,0.3 \mathrm{mg} / \mathrm{mL}$ respectively.

\section{Interference studies with bilirubin}

The interference of endogenous interferent bilirubin is tested as part of the performance of the proposed qualitative and semi quantitative latex reagent. To evaluate the effects of hyper bilirubinemia, the left over clinical samples with different total bilirubin values ranging from $(0.5 \mathrm{mg} / \mathrm{dL}$ to $2 \mathrm{mg} / \mathrm{dL})$ is chosen. The quantitative value of Hs CRP is done on fully automated analyzer $\mathrm{BN}$ prospec II.

\section{Sample analysis}

Clinical leftover samples was tested both qualitatively and semi quantitatively and compared with existing reagent system to confirm the quality of the prepared reagent system.

\section{Results and Discussion}

The study protocol was approved by the Institutional Research Ethics Committee of Agappe Diagnostics, Agappe hills, Pattimattom [reference number: R\&D/IEC/20.11.2015]. The antibody against human $\mathrm{C}$ reactive protein obtained commercially from ABCAM, Mybio Source, Mybio, and Sigma Aldrich and purified by the affinity chromatographic technique. The efficiency of assay was checked by visible agglutination reaction pattern with the highest and lowest CRP calibrator. The selected latex bead with the best functional group from the trial was used for the assay preparation (Fig. $1)$.

\section{Covalent binding of anti Hs CRP to the latex protocol development}

Thermoscientific beads, Sigma, and Magsphere are the different latex beads selected in different concentration; these beads are washed and diluted using a washing buffer to the 0.1 to $1.0 \% \mathrm{v} / \mathrm{w}$ concentration. These diluted latex beads are subjected to an activation process by incubating with anti CRP protein such as ABCAM Mouse Monoclonal $\mathrm{C}$ reactive Antibody, Mybio Source Mouse monoclonal $\mathrm{C}$ reactive Antibody, Mybio source Goat Polyclonal C reactive Antibody, Sigma Aldrich Mouse monoclonal $\mathrm{C}$ reactive Antibody. The passive adsorption property is checked with 6 hours incubation with $50 \mu \mathrm{l}$ anti CRP antibody solution of $5 \mathrm{mg} / \mathrm{ml}$. The coated latex is checked for visual agglutination with the CRP positive control serum on the black slides.

All different source latex showed similar reactions (Table 1), when compared, medium sized particles as $0.46 \mu \mathrm{m}, 0.49 \mu \mathrm{m}$ and 0.5 $\mu \mathrm{m}$ showed better reaction. Latex of size $0.49 \mu \mathrm{m}, 0.46 \mu \mathrm{m}$ and $0.50 \mu \mathrm{m}$ showed similar reactions with all 4 different anti CRP 
antibody sources and with the control serum. Upon the cost and availability Thermo fisher latex of size $0.46 \mu \mathrm{m}$ with functional modification as carboxyl modified latex selected for further studies. Purified Polyclonal Goat Anti CRP from Advy Chemicals showed good reactions with known Hs CRP concentrations and control. Covalent coupling protocol for $\mathrm{Hs}$ CRP coating on carboxyl modified $0.46 \mu \mathrm{m}$ done with the protocol described and checked for its agglutination. The latex suspension is now at approx. $1 \%$ solids. More trials was done with clinical samples of $\mathrm{Hs}$ CRP concentration $1 \mathrm{mg} / \mathrm{L}, 4 \mathrm{mg} / \mathrm{L}$ and $10 \mathrm{mg} / \mathrm{L}$ by Siemens BN Prospec fully automated analyzer (Table 2). Coarse agglutination with central clearing was found with $4 \mathrm{mg} / \mathrm{L}$ and $10 \mathrm{mg} / \mathrm{L}$ concentration Hs CRP along with Positive control, $1 \mathrm{mg} / \mathrm{L}$ concentration Hs CRP shows a coarse agglutination without central clearing and saline shows a very fine agglutination.

\section{Antibody titration for optimal coating}

The assay was again tested for the titration of protein that was coupled to the latex beads using BCA assay to optimize the minimum amount of anti CRP antibody required to saturate the latex beads. The amount of anti CRP antibody required to coat for a monolayer of latex is calculated. Different trials are done to estimate the amount of protein to be used to achieve the maximum saturation with minimum concentration of anti CRP antibody (Table 3).

\section{Micro Protein estimation with BCA assay}

The supernatant obtained during the washing procedure after the covalent coupling is done using the BCA assay. The two concentration of anti CRP antibody used are $100 \mu \mathrm{l}$ and $150 \mu \mathrm{l} \quad(5 \mathrm{mg} / \mathrm{ml})$ to $1 \mathrm{ml}$ of $1 \%$ latex suspension. Protein optimisation trial yield as $500 \mu \mathrm{g}-750 \mu \mathrm{g}$ of Anti CRP required for $1 \mathrm{mg}$ weight latex. Bound Protein estimation studies showed approx 250-350 $\mu \mathrm{g}$ is bounded to $1 \mathrm{mg}$ weight latex (Table 4).

\section{Reaction buffer characterization for colloidal stability}

The trial reagent was checked for colloidal stability at room temperature, $37^{\circ} \mathrm{C}$ and $45^{\circ} \mathrm{C}$ using different stabilizing agents such as BSA, PEG 600, Tween 80, Fish skin gelatin, Tween 60 in the final reaction buffer (Tris buffer). $1 \%$ of the trial stabilizing agents was used in the buffer and the latex kept at three different temperature for7days. The latex assay was then checked for auto-agglutination in saline after the 7 days of incubation (Table 5). Comparing the different stabilizing agents used, BSA (Bovine serum albumin) $1 \% \mathrm{w} / \mathrm{v}$ showed good colloidal stability at room temperature and at $37^{\circ} \mathrm{C}$. Higher temperature showed agglutination reaction with all agents used.

\section{Performance validation of the assay}

\section{Sensitivity and specificity}

The sensitivity of the trial reagent was set as $1 \mathrm{mg} / \mathrm{L}$. The measurement range for the Hs CRP qualitative reagents are established as $<1 \mathrm{mg} / \mathrm{L}$ to $<10 \mathrm{mg} / \mathrm{L}$ as the approved FDA guidelines. The trial reagent is measured along the analytical range of $1 \mathrm{mg} / \mathrm{L}$ to 10 $\mathrm{mg} / \mathrm{L}$ using the CRP calibrator (Table 6).

\section{Precision}

Approved guideline and protocol were used to evaluate the precision, testing has to done with 20 replicates of negative and positive samples at concentration within $20 \%$ of the cutoff (Table 7). 
Table.1 Preliminary coupling reaction - Grading of Visual agglutination reaction with CRP positive control serum

\begin{tabular}{|l|c|c|c|c|c|}
\hline Latex NO & Latex size $(\mu \mathrm{m})$ & Antibody 1 & Antibody 2 & Antibody3 & Antibody 4 \\
\hline Latex 1 & 0.33 & + & + & $2+$ & + \\
\hline Latex 2 & 0.49 & $3+$ & $3+$ & $3+$ & $3+$ \\
\hline Latex 3 & 082 & $2+$ & $2+$ & $2+$ & $2+$ \\
\hline Latex 4 & 0.46 & $3+$ & $3+$ & $3+$ & $3+$ \\
\hline Latex 5 & 0.6 & $2+$ & $2+$ & $2+$ & $2+$ \\
\hline Latex 6 & 0.8 & $2+$ & $2+$ & $2+$ & $2+$ \\
\hline Latex 7 & 0.5 & $3+$ & $3+$ & $3+$ & $3+$ \\
\hline Latex 8 & 0.6 & $2+$ & $2+$ & $2+$ & $2+$ \\
\hline Latex 9 & 0.8 & $2+$ & $2+$ & $2+$ & $2+$ \\
\hline
\end{tabular}

+- Very fine agglutination without central clearing, 2+- Coarse agglutination without central clearing, 3+ - Coarse agglutination with central clearing.

Table.2 Reactions of HsCRP coated latex with serum of known concentrations

\begin{tabular}{|l|l|l|l|l|l|l|}
\hline Latex No & Latex size & \multicolumn{5}{|c|}{ Concentration Hs CRP } \\
\cline { 3 - 7 } & & $\mathbf{1 m g / L}$ & $\mathbf{4 m g / L}$ & $\mathbf{1 0} \mathbf{~ m g / L}$ & Pos control & Saline \\
\hline Latex 2 & $\mathbf{0 . 4 9} \boldsymbol{\mu m}$ & ++ & +++ & +++ & +++ & + \\
\hline Latex 4 & $\mathbf{0 . 4 6} \boldsymbol{\mu m}$ & ++ & +++ & +++ & +++ & + \\
\hline Latex 7 & $\mathbf{0 . 5 0 \mu m}$ & ++ & +++ & +++ & +++ & + \\
\hline $\begin{array}{l}\text { '+' : Very fine agglutination, '++' : Coarse agglutination without central clearing, } \\
\text { '+++': Coarse agglutination with central clearing }\end{array}$ \\
\hline
\end{tabular}

Table.3 Reactions of different concentration of anti CRP coated Latex

\begin{tabular}{|l|l|l|l|l|l|l|}
\hline Conc. Of Anti & \multicolumn{5}{|c|}{ Observed reactions on slide } \\
$\begin{array}{l}\text { CRP(5mg/ml) in } \\
\boldsymbol{\mu} \mathbf{L} \text { for 1ml 1\% } \\
\text { latex }\end{array}$ & $\begin{array}{l}\text { Positive } \\
\text { control }\end{array}$ & $\begin{array}{l}\text { Negative } \\
\text { Control }\end{array}$ & $\begin{array}{l}\text { Normal } \\
\text { saline }\end{array}$ & $\begin{array}{l}\text { Serum } \\
\text { CRP } \\
2 \mathrm{mg} / \mathrm{L}\end{array}$ & $\begin{array}{l}\text { Serum Hs } \\
\text { CRP conc } \\
10 \mathrm{mg} / \mathrm{L}\end{array}$ \\
\hline $\mathbf{5 0}$ & +++ & - & - & + & + \\
\hline $\mathbf{1 0 0}$ & +++ & - & - & ++ & ++ \\
\hline $\mathbf{1 5 0}$ & +++ & - & - & +++ & ++ \\
\hline $\mathbf{2 0 0}$ & +++ & - & $+/-$ & ++ & +++ \\
\hline $\mathbf{2 5 0}$ & +++ & - & + & ++ & +++ \\
\hline $\mathbf{5 0 0}$ & & +++ & - & + & + & +++ \\
\hline
\end{tabular}


Table.4 Protein estimation using BCA assay in supernatant solution after coupling

\begin{tabular}{|l|c|c|c|c|}
\hline \multirow{2}{*}{$\begin{array}{l}\text { Initial } \\
\text { Concentration } \\
\text { coated }\end{array}$} & \multicolumn{2}{|c|}{ Conc. of protein in supernatant $(\boldsymbol{\mu g} / \mathbf{m l})$} & $\begin{array}{l}\text { Apporx Conc } \\
\text { on latex }\end{array}$ \\
\cline { 2 - 5 } & $1^{\text {st }}$ wash & $2^{\text {nd }}$ wash & $3^{\text {rd }}$ wash & \\
\hline $\mathbf{5 0 0} \boldsymbol{\mu g}$ & 107.5 & 94 & 30 & 268.5 \\
\hline $\mathbf{7 5 0} \boldsymbol{\mu g}$ & 235 & 102 & 56 & 357 \\
\hline
\end{tabular}

Table.5 Auto-Agglutination reactions on different temperature with different stabilizer

\begin{tabular}{|l|l|l|l|}
\hline Stabilizer in Buffer $(1 \%$ w/v $)$ & At RT & $37^{\circ} \mathbf{C}$ & $45^{\circ} \mathbf{C}$ \\
\hline BSA & - & - & + \\
\hline PEG 600 & $-/+$ & + & ++ \\
\hline Tween 80 & - & - & + \\
\hline Fish skin gelatin & - & - & + \\
\hline Tween 60 & - & $-/+$ & ++ \\
\hline
\end{tabular}

Table.6 Diagnostic test evaluation for precision study of the trail reagent

\begin{tabular}{|l|l|l|l|}
\hline Statistic & Formula & Value & $\mathbf{9 5 \%}$ CI \\
\hline Sensitivity & $\mathrm{a} /(\mathrm{a}+\mathrm{b})$ & $90.00 \%$ & $68.30 \%-98.77 \%$ \\
\hline Specificity & $\mathrm{d} /(\mathrm{c}+\mathrm{d})$ & $95.00 \%$ & $75.13 \%-99.87 \%$ \\
\hline $\begin{array}{l}\text { Positive } \\
\text { Likelihood Ratio }\end{array}$ & $\begin{array}{l}\text { Sensitivity/(1- } \\
\text { Specificity) }\end{array}$ & 18.00 & $2.65-122.28$ \\
\hline $\begin{array}{l}\text { Negative } \\
\text { Likelihood Ratio }\end{array}$ & $\begin{array}{l}\text { (1-Sensitivity) } \\
\text { Specificity }\end{array}$ & 0.11 & $0.03-0.39$ \\
\hline
\end{tabular}

Table.7 Diagnostic test evaluation for precision study of the trail reagent

\begin{tabular}{|l|l|l|l|l|l|}
\hline & \multicolumn{5}{|c|}{ Disease } \\
\hline Test & Present & n & Absent & n & Total \\
\hline Positive & True Positive & $\mathrm{a}=18$ & $\begin{array}{l}\text { False } \\
\text { Positive }\end{array}$ & $\mathrm{c}=1$ & $\mathrm{a}+\mathrm{c}=19$ \\
\hline Negative & $\begin{array}{l}\text { False } \\
\text { Negative }\end{array}$ & $\mathrm{b}=2$ & $\begin{array}{l}\text { True } \\
\text { Negative }\end{array}$ & $\mathrm{d}=19$ & $\mathrm{~b}+\mathrm{d}=21$ \\
\hline Total & & $\mathrm{a}+\mathrm{b}=20$ & & $\mathrm{c}+\mathrm{d}=20$ & \\
\hline
\end{tabular}


Table.8 Agglutination pattern observed in Intra run precision study with known concentration of sample

\begin{tabular}{|c|c|c|c|}
\hline \multirow[t]{2}{*}{ Repeats } & \multicolumn{3}{|c|}{ Concentration of Hs CRP } \\
\hline & $\begin{array}{l}\text { Direct sample } \\
4 \mathrm{mg} / \mathrm{L}\end{array}$ & $\begin{array}{l}1 / 2 \text { diluted sample } \\
2 \mathrm{mg} / \mathrm{L}\end{array}$ & $\begin{array}{l}1 / 4 \text { diluted sample } \\
1 \mathrm{mg} / \mathrm{L}\end{array}$ \\
\hline Repeat no.1 & +++ & ++ & + \\
\hline Repeat no.2 & +++ & ++ & + \\
\hline Repeat no.3 & +++ & ++ & + \\
\hline Repeat no.4 & +++ & ++ & + \\
\hline Repeat no.5 & +++ & ++ & + \\
\hline Repeat no.6 & +++ & ++ & + \\
\hline Repeat no.7 & +++ & ++ & + \\
\hline Repeat no.8 & +++ & ++ & + \\
\hline Repeat no.9 & +++ & ++ & + \\
\hline Repeat no.10 & +++ & ++ & + \\
\hline
\end{tabular}

Table.9 Trial latex reagent agglutination with different concentration of hemolysate in serum containing CRP

\begin{tabular}{|l|l|l|l|}
\hline \multirow{2}{*}{ Hemolysate conc (mg/ml) } & \multicolumn{3}{|l|}{ Hs CRP concentration in Pooled serum } \\
\cline { 2 - 4 } & $1 \mathrm{mg} / \mathrm{L}$ & $5 \mathrm{mg} / \mathrm{L}$ & $10 \mathrm{mg} / \mathrm{L}$ \\
\hline $\begin{array}{l}\text { Without hemolysate } \\
\text { (control) }\end{array}$ & ++ & +++ & +++ \\
\hline With $6 \mathrm{mg} / \mathrm{ml}$ & + & ++ & +++ \\
\hline With $3 \mathrm{mg} / \mathrm{ml}$ & + & ++ & +++ \\
\hline With $1.5 \mathrm{mg} / \mathrm{ml}$ & ++ & +++ & +++ \\
\hline With $0.6 \mathrm{mg} / \mathrm{ml}$ & ++ & +++ & +++ \\
\hline With $0.3 \mathrm{mg} / \mathrm{ml}$ & + & +++ & +++ \\
\hline
\end{tabular}


Fig.1 Agglutination slide showing linearity study with different calibrator concentration

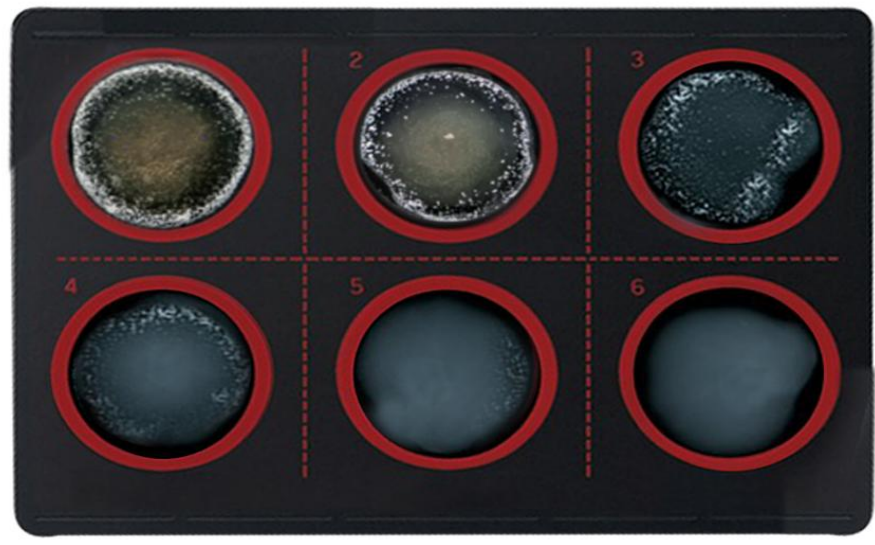

Two samples were made by values hiked using the CRP calibrator, the values taken was 0.8 $\mathrm{mg} / \mathrm{L}$ as negative and $1.2 \mathrm{mg} / \mathrm{L}$ as positive value. The agglutination was replicated 20 times at the same laboratory condition. False positive and false negative incidence was studied.

\section{Intra run study -Precision study}

The trial reagent is checked qualitatively and semi quantitatively the agglutination within the same run. A sample of known value of $4 \mathrm{mg} / \mathrm{L}$ (Immuno turbidimetrically estimated) is used for the intra run study. Agglutination was done at the same laboratory conditions. Ten repeats was done on direct sample and $1 / 2$ dilution and $1 / 4$ dilution with saline. There was no difference in the pattern of agglutination noted (Table 8).

\section{Inter run study - Precision study}

The trial reagent was checked qualitatively and semi quantitatively the agglutination between the run. A sample of known value of $4 \mathrm{mg} / \mathrm{L}$ (immuno turbidimetrically estimated) was used for the inter run study. Agglutination was done at different time such as $10 \mathrm{am}, 1.30 \mathrm{pm}$ and $4 \mathrm{pm}$ in the same laboratory conditions. Ten repeats were done on direct sample and $1 / 2$ dilution and $1 / 4$ dilution with saline. There was no difference in the pattern of agglutination noted.

\section{Studies of Interference substance testing}

\section{Interference from hemoglobin}

From the interference study of hemolysate reaction it is noted that there is reduction in agglutination $6 \mathrm{mg} / \mathrm{ml}$ and $3 \mathrm{mg} / \mathrm{ml}$ hemolysate showed a reduction in agglutination reactions towards the lower side. But the reaction is not seen to be inhibited even at the lower side sensitivity (Table 9).

\section{Interference studies with Bilirubin}

The interference of endogenous intereferent, bilirubin is tested as part of the performance validation. A total of 20 samples studied which was having different Hs CRP values. All Hs CRP values are classified as 3 quadrants based on the value obtained.

The 5 samples were found with the value of $1 \mathrm{mg} / \mathrm{dL}$ or less, 10 samples were between $1 \mathrm{mg} / \mathrm{dL}$ and $4 \mathrm{mg} / \mathrm{dL}$, and 5 samples were found to have above $4 \mathrm{mg} / \mathrm{dL}$. All three quadrants have total bilirubin values ranging from $(0.5 \mathrm{mg} / \mathrm{dL}$ to $2 \mathrm{mg} / \mathrm{dL}$ ). Agglutination reactions were observed with the trial latex reagents. Interference was defined as a significant and consistent reduction in the visual agglutination pattern from the expected agglutination. We observed no interference from bilirubin in any of the samples studied. 


\section{Sample comparison}

The prepared reagent system was tested with clinical left over samples with known values of hs CRP with existing reagent systems. The results in test reagent system were compared and found as similar to that of the standard reagent system.

In conclusion, the detection of Hs CRP using various quantitative method is used in clinical practice. But the use of a rapid qualitative and semiquatative latex agglutination protocol has not been reported. Presently as a point of care method for screening patients for the level of Hs $\mathrm{CRP}$ at low resource centers can be employed with this novel protocol. The present reagent formulation is rapid, cost effective, reproducible and is comparable with the reference method used in clinical practice.

The advantage of this proposed methodology is that it does not require any high end automated systems for the estimation. This can be used in primary health care centers to monitor the subclinical inflammation of patients at risk of any impending CVD. However this method needs to be studied in different populations for establishing its clinical utility.

\section{References}

1. Prabhakaran D, Jeemon P, Roy A. Cardiovascular diseases in India: current epidemiology and future directions. Circulation. 2016 Apr 19; 133(16): 160520.
2. Callahan D. Taming the beloved beast: how medical technology costs are destroying our health care system. Princeton University Press; 2018 Jan 8.

3. Chow SL, Maisel AS, Anand I, Bozkurt B, De Boer RA, Felker GM, Fonarow GC, Greenberg B, Januzzi Jr JL, Kiernan MS, Liu PP. Role of biomarkers for the prevention, assessment, and management of heart failure: a scientific statement from the American Heart Association. Circulation. 2017 May 30; 135(22):e105491.

4. Lam CS, Castillo R, Ho DT, Kasliwal RR, Khurana R, Naik S, Omland T, Parsonage WA, Phrommintikul A, Tobing D, Yiu KK. High-sensitivity troponin I for cardiovascular risk stratification in the general asymptomatic population: Perspectives from Asia-Pacific. International journal of cardiology. 2019 May 1; 282:93-8.

5. Shahid R. Examination of the CrossSectional Association between Insulin Resistance (HOMAIR) and an Inflammatory Marker (CRP) in a Representative Canadian Non-Diabetic Population (Doctoral dissertation, University of Saskatchewan).

6. Sridhar R, Pliszka D, Luo HK, Chin Lim KH, Ramakrishna S. Medical devices regulatory aspects: a special focus on polymeric material based devices. Current pharmaceutical design. 2015 Dec 1; 21(42): 6246-59.

\section{How to cite this article:}

Praveena, C.V. Raghuveer and Vasudevan, D.M. 2019. Development of Latex Enhanced Qualitative Immuno Assay for High Sensitivity CRP Detection. Int.J.Curr.Microbiol.App.Sci. 8(06): 2638-2647. doi: https://doi.org/10.20546/ijcmas.2019.806.317 